Julie Arendt and Mary K. Taylor

\title{
When the walls crash down Offer services where the students are
}

\section{The incident}

It started like any other Monday at Southern Illinois University Carbondale's Morris Library. It was late in the semester. Students were busy at the library computers, working on homework or just surfing the Web. A couple of librarians were at the information desk. The first floor and the basement of the library were open and in use, but the other six floors of the building were closed. Occasionally, it felt like the library building was shaking, as construction equipment rumbled overhead on the upper floors. The library was in the thick of a multi-year construction and renovation project. It had taken months and months of planning. The contractor was hired and work was finally underway.

The library staff was beginning to get used to the nearly continuous rumbling and shaking. Equipment punched holes in the exterior walls to remove the brick facade. Suddenly there was a huge crash, much louder than any previous rumbling, and then all noise stopped. Something was not right. A huge section of bricks had unexpectedly fallen off one side of two upper floors of the building and had sliced like a knife into the roof of the third floor.

Fortunately, no one was injured by the plummeting bricks. Until it was certain that more bricks would not fly off the building, the library was off limits. Everyone in the library had to evacuate. Anything inside the library building became inaccessible.

The loss of the main library building was not as devastating as it could have been. The library had switched to electronic delivery for many of its journals, and the servers for those resources were in another building.
To prepare for the construction project, the library had moved more than 80 percent of the collection to off-site storage. Two thirds of the library staff members were in offices in other buildings. Nevertheless, important parts of the collection were unreachable. We temporarily lost our print reserves collection, our newer print journals and books, and our print reference collection. We could not access any of the books from storage and interlibrary loan that were being held at the circulation desk for patrons. We also lost access to the Map Library, the Curriculum Materials Center, special format materials, and the preservation department offices.

\section{The response}

The library administration rushed to mitigate the problems. They had plenty of concerns, including building safety, public relations, and alternate work for displaced employees. Working with the campus administration and information technology administrators, they found a location to continue to offer library services near the center of campus at the help desk of a computer lab.

The circulation department squeezed as many book trucks as they could into the small space, so patrons could pick up materials delivered from off-site storage and interlibrary loan, as well as return materials. Reference and circulation staff shared the same desk

Julie Arendt is reference librarian-sciences, e-mail: jarendt@lib.siu.edu, and Mary K. Taylor is medical and distance learning librarian, e-mail: mtaylor@lib.siu.edu, at Southern Illinois University-Carbondale

๑) 2006 Julie Arendt and Mary K. Taylor 
and computer. The student newspaper and campus staff newsletter ran stories about the temporary location, and liaison librarians notified their departments.

The librarian in charge of the chat reference service requested that we extend chat reference hours. She did not create a formal schedule, but the extended hours just happened. Reference staff logged on early and stayed on late to be there for people's questions.

During the first day following the construction incident, chat reference got a surge of questions. After that, it slowed down. Library staffers were there to answer questions, but the questions were not coming. The library did not get many reference questions at the service desk in the computer lab either. People were coming to the makeshift library to pick up and return books or to ask when the library would reopen, but for the most part, people were not coming there for research assistance.

\section{Taking service to the students}

One evening, two reference librarians chatted about this silence in online reference. They both felt like there was something more that they should be doing to provide service while the building was closed. The computer lab was not drawing much traffic, and neither was online reference. Where else could the library go, and what else could the library do?

After this chat, one of the librarians emailed her boss with the suggestion that the library take a laptop and offer roaming reference services in places where the students study. On Friday morning, the associate dean, already swamped with problems related to the construction incident, responded with an e-mail to all the reference librarians saying that it was a great idea and that anyone who was willing to coordinate it was welcome to do so. By Friday afternoon, no one had volunteered to be the coordinator.

That afternoon, the authors of this paper talked about the lack of volunteers, and quickly we became the volunteers. We came up with a short list of necessary materials: a laptop with a wireless Internet connection, library bookmarks, scrap paper, pens, signs, and nametags. One of us asked a student worker where students ordinarily studied, and based on her recommendation, we decided to offer roaming reference at the student center. One librarian volunteered to go there the following Monday and Tuesday evening, and the other volunteered to go on Wednesday and Thursday evening. We borrowed a laptop from the instructional support services department of the library. While we were requesting the laptop, we bumped into the manager of instructional support services and told him about our plan. He thought it was a great idea and allowed us to "jump the line" for graphics work. This assistance gave us professional-looking signs by Monday evening, instead of the normal two-week production time. We sent an e-mail to the student center to let them know that we would be there, and we sent an e-mail to the other librarians to seek volunteers to take daytime shifts at the student center in addition to their shifts at the computer lab. Within an hour or two, we had planned off-site reference and put the pieces in place to make it happen.

A few of the plans changed during the next week. Librarians volunteered to work at the student center, so we expanded our planned service hours. On Monday morning, the student center e-mailed back that they would prefer us to take a table rather than to roam. They offered to provide a table and to post signs about the service near all of the building's entrances. The library administrative office supplied us with an official library tablecloth to cover the table. By Monday night, we were ready to go.

When we first went to the student center, we did not know what to expect. Would we spend hours on end doing nothing? If we could help just one person, it would be better than nothing, but would it be worth the effort? On the first night, our concerns were allayed. The table, in a prime location in the middle of the first floor of the student center, was certainly busier than the desk at the computer lab, and it was at least as busy as the reference desk of the library had been. Of course, 
a few people stopped to complain about the inconvenience of the library closure. A number of questions were for basic information about what had happened to the library and when it would reopen. Some of the questions were the informational questions that ordinarily were asked at the library reference desk. With the laptop, we were able to respond. For example, one librarian helped a group of students who were working in the coffee shop on a sociology paper. As the week progressed, we added more service hours as librarians saw that service at the student center was not a waste of time.

\section{The lessons}

The library reopened on the second Saturday after the construction incident. Reference service at the student center was over, and it had been a success. We do not plan to have the walls of the library crash down again, but we take away some lessons from the experience to help us in our day-to-day work.

1) Leverage informal conversations. The idea to offer reference services in the student center did not come from a formal crisis management meeting; it came from a "water cooler" conversation between librarians. The decision of where to offer the service did not come from a formal survey of different possible locations on campus, it came from passing a student worker in the hall. These conversations by themselves could have stayed just conversations, but instead they were a springboard for action. The opportunity to use informal conversations as a springboard is there, even when the walls are not falling down. The key is to use these conversations to learn from one another and to get new ideas and then to follow up on the conversation with action.

2) Start small and see what happens. The emergency closure of the library forced us to offer off-site reference with a minimum of planning and preparation. If we had more time to plan, we may have done more to recruit staff and to set regular hours. Additional planning would not necessarily have made the service better. We did not know at the outset if anyone would talk to us at the student center or if anyone would ask research questions. Out-of-library reference service at other universities has met with success ${ }^{1}$ and with failure. ${ }^{2}$ By starting small, with just a few hours and a couple librarians, we were able to test the waters. If there had been no response or a negative response to our presence at the student center, we would have lost little for our efforts. We can take a similar approach when we get good and not-so-good ideas for new programs and services for the library. Starting small and seeing what happens is an easy way to separate the good ideas from the bad ideas.

3) Pay it forward. The student center provided a table and advertising for us. Instructional support services made a rush-order sign for us. Librarians volunteered to work extra reference shifts. None of these people had to put in this extra effort, but they did so because the library was in an extraordinary situation. The goodwill and help above and beyond what they had to do continues to encourage us to offer not just goodwill but to go the extra mile for others.

\section{Afterward}

Now that the building has reopened, Morris Library is continuing to test the waters of offsite reference. The library will set up a table at the student center again during the busiest weeks of the fall semester. If this service is successful, the library may expand off-site services by pulling staff from the information desk and putting them in other locations on campus.

\section{Notes}

1. A. Ben Wagner, "On-site reference services and outreach: Setting up shop where our patrons live" (paper presented to the Special Libraries Association National Meeting, Nashville, Tennessee, June 8, 2004), www.acsu. buffalo.edu/ abwagner/Outreach-SLAPaper2004.htm (accessed June 7, 2006).

2. Julia K. Nims, "Meeting students on their own turf," Research Strategies 16, no. 1 (1998): 85-89. n 